\title{
The Impact of the Scottish Parliament in Amending Executive Legislation
}

\author{
Mark Shephard and Paul Cairney
}

This paper provides the first systematic attempt to investigate the legislative impact of the Scottish Parliament on Executive legislation by analysing the fate of all amendments to Executive bills from the Parliament's first session (1999-2003). Initial findings on the success of bill amendments show that the balance of power inclines strongly in favour of ministers. However, when we account for type of amendment and initial authorship we find evidence that the Parliament (both coalition and opposition MSPs) actually makes more of an impact, particularly in terms of the level of success of substantive amendments to Executive bills. Findings have implications for much of the current literature that is sceptical of the existence of power sharing between the Executive and the Parliament and within the Parliament.

\section{About the Authors}

Mark Shephard, Lecturer in Politics, Department of Government, University of Strathclyde, McCance Building, 16 Richmond Street, Glasgow G1 1XQ, UK; email: mark.shephard@,strath.ac.uk

Paul Cairney, Researcher, Department of Politics and International Relations, University of Aberdeen, Edward Wright Building, Dunbar Street, Aberdeen, AB24 3QY, UK; email: paul.cairney@abdn.ac.uk

\section{Notes}

This research was financed by the British Academy (Grant SG-35124) whose assistance is gratefully acknowledged. Link to publisher's version of this article: http://onlinelibrary.wiley.com/doi/10.1111/j.14679248.2005.00530.x/abstract The definitive version is available at www.wileyonlinelibrary.com.

This paper provides the first systematic attempt to investigate the legislative impact of the Scottish Parliament on Executive legislation by analysing the fate of all amendments to Executive bills from the Parliament's first 
session (1999-2003). Initial findings on the success of bill amendments show that the balance of power inclines strongly in favour of ministers. However, when we account for type of amendment and initial authorship we find evidence that the Parliament (both coalition and opposition MSPs) actually makes more of an impact, particularly in terms of the level of success of substantive amendments to Executive bills. Findings have implications for much of the current literature that is sceptical of the existence of power sharing between the Executive and the Parliament and within the Parliament.

Much has been written about the campaign and establishment of the Parliament (Mitchell, 1996; Taylor, 1999), the mechanics of how the Parliament works in theory (Hassan, 1999; McFadden and Lazarowicz, 2000; Lynch 2001), and legitimation and representation issues (Shephard et al., 2001). However, beyond anecdotal evidence ${ }^{\mathrm{i}}$ and beyond the study of MSP perceptions (Arter 2002a; Scottish Council Foundation, 2002; Arter 2004), we do not have any systematic indicators of the extent to which the Parliament is having an impact on Executive legislation. This is a particular drawback in Scotland; given that devolution was heralded as an opportunity to deliver a 'new politics' that would be different from the 'old politics' of Westminster. One of the features of this 'new politics' is the sharing of power between the Executive and the Parliament.

\section{New Politics, Power Sharing and Balance of Power}

What is 'new politics'? 'New politics' is a rather vague concept (Mitchell, 2000, p. 605) that has been variously deployed and defined. Deployment of the term 'new politics' in the Scottish context originates in the rhetoric and expectations of the home rule movement. While several aspects of the new Scottish Parliament were based on the workings of Scandinavian parliaments (see Arter, 2002b), it is understandable that much of the comparisons of 'old' and 'new' were with Westminster. For example, the search for 'consensus' was borne out of a frustration with Westminster adversarial politics and the focus on strong and non-partisan committees was based on the shortcomings of a charged political atmosphere with plenary sessions rather than committees as the main driver. Setting out the demands for a Scottish Parliament, for example, the Labour-led Scottish Constitutional Convention (SCC) hoped that:

...the coming of a Scottish Parliament will usher in a way of politics that is radically different from the rituals of Westminster: more participative, more creative, less needlessly confrontational (SCC, 1995). 
These wishes were largely incorporated into the 1997 White Paper, Scotland's Parliament, following the election of Labour earlier that year. Reporting on the rules of procedure and Standing Orders of the Parliament, the Consultative Steering Group (CSG) recommended four underlying principles: power sharing; accountability; equal opportunities; and openness and participation.

These four principles are illustrative of the features characterising a 'new politics', but scope, and hence definitions, vary. James Mitchell identifies three core aspects of new politics rhetoric: new institutions, new processes and a new political culture (2000, p. 605). He argues that while new institutions have been realised, and new policy-making processes have been partly realised, the new political culture has largely failed to materialise. Consequently, Mitchell argues that expectations of Parliament's policy-making position vis-à-vis the Executive have been oversold (Mitchell, 2000, p. 606).

Much of the evidence from MSPs to date shows a similar dissatisfaction with the practice of 'new politics' (see Scottish Council Foundation, 2002). MSP concerns have ranged from the low quality of debates and a lack of focus and organisation, to high degrees of party influence and control (for example, over committee voting and selection of convenor) and concerns over Executive control over Bills and the parliamentary timetable (SCF, 2002). More recently, a 2003 Procedures Committee report on the founding principles of the Parliament warns strongly against the Parliament becoming a 'conveyor belt for passing legislation' to the detriment of quality scrutiny and influence (Procedures Committee, 2003, paragraph 1016). Of the 135 recommendations advocated to improve the practice of the four principles, nearly half related to recommendations designed to improve the 'power sharing' principle:

Power sharing was designed to be the key to creating a new model of governance in Scotland, synthesising traditional representative democracy with elements of a more participative model, and, while we have made recommendations in relation to all four CSG principles, our conclusions suggest that it is in relation to power sharing that most progress remains to be made (Procedures Committee, 2003, paragraph 1003).

Adopting a wide view of power sharing, David Arter (2004) defines 'new politics' as a trilateral sharing of power between the Executive, Parliament and People. Arter also identifies additional features of power sharing in his analysis, namely power sharing within the Executive and power sharing within the Parliament (to which might logically be added power sharing within society). He argues that evidence of 'new politics' is most likely to be found by analysing the defining new feature of the Scottish Parliament, the committee system, and 
legislative output of the Parliament as a whole. However, Arter's analysis of the committee system is a 'brief inventory' that touches on the big picture of committee activities and successes to date. Measures include the number of committee bills enacted, number of inquiries conducted, number of petitions considered, number of committee meetings held outside the Parliament, and committee incumbency levels.

Arter finds evidence of power sharing between Parliament and the Scottish people that does have policy-making consequences (albeit constrained by the prevalence of partisanship). He also argues that the CSG envisaged power sharing between the Executive and outside organisations. However, power sharing between the Executive and the Parliament proved more complex. While parliamentary influence is demonstrated by the allocation of competencies to committees and the right to initiate legislation, the CSG envisaged a system in which the Executive were still able to 'govern' - suggesting effective parliamentary scrutiny and influence of the Executive rather than power sharing per se.

Most of the commentary on Parliament's successes has focused on the Member and Committee Bills that have been enacted (see for example, Shephard 2001-2003; Arter 2004). Leaving aside the well-trodden analysis of areas where the Parliament can initiate its own legislation, we focus our analysis on Parliament's reaction to and successes in influencing Executive legislation. Whereas Arter uses interview examples with MSPs to support his argument that government-opposition relations have been similar to those in the House of Commons, we analyse the fate of every amendment to Executive Bills to more closely examine the nature of this relationship. If Arter is right about the nature of the balance of power we would expect to find that the balance inclines strongly in favour of ministers and parliamentarians from the coalition parties. While it may still be too early to pass judgement, we do at least have one full session ${ }^{\text {ii }}$ of parliamentary data on which to make an assessment in terms of amendments to Executive Bills.

Analysis of amendments is not the only test that could be used but it is a key indicator of parliamentary influence that has been largely neglected in British analyses since Griffith's (1974) study of the Westminster Parliament. By contrast, the comparative European literature has made more use of this kind of analysis (see for example, Tsebelis 2001; Kreppel 2002). The comparative European literature is also instructive in that it provides a comparative context within which the Scottish Parliament can be assessed. 


\section{The Scottish Parliament and the Comparative European Context}

Initial evaluations of convergence/ divergence in Holyrood and Westminster bills (see Keating et al., 2003) shows that devolution has not provided an institutional revolution on the scale of that witnessed in the emerging parliaments of Central and Eastern Europe (see for example, Olson and Norton, 1996; Arter, 2002b). Dramatic change in Scotland is undermined for a number of reasons, including the blurred boundaries between reserved and devolved matters, the UK's single market and welfare state, common UK security issues, the UK's position within the EU, party and ministerial links, civil service uniformity and the prevalence of Sewel motions (see Keating, 2005; Cairney and Keating, forthcoming). Western European comparisons are arguably more appropriate and in this vein our in-depth focus is on the ability of parliaments to influence rather than initiate legislation ${ }^{\text {iii }}$.

So what should we expect of Western European legislatures? In Polsby's (1975, in Norton, 1998) terms, while the US legislature is 'highly transformative', West European legislatures range from 'modified transformative' (Holland and Sweden), to 'modified arena' (Germany, Italy, UK) and 'arena' (Belgium and France). Norton's (1998) more recent rankings of the policy effect has Italy, Holland and Scandinavian parliaments as the most influential, Germany, Belgium and the UK in the middle, with Ireland and France as the least influential. But where does Scotland fit in?

Arter's (2002b) qualified argument is that Scotland has a Scandinavian-style assembly, with (unlike Westminster) a strong committee system at its core. Further, in Mattson and Strøm's (2004, p. 100-1) terms, these committees compare very favourably with those in other Western European systems in terms of the indicators of committee strength. However, as Arter (2002b) recognises, there is no current need for the leading party coalition (of Labour and Liberal Democrats) to engage in power sharing with opposition parties (such as the Scottish National Party and the Conservative Party). Therefore, as Mitchell (2000) argues, if the political culture of power sharing is largely absent then party cohesion and coalition dominance may undermine the effectiveness of these new resources.

If we accept that the leading party coalition has no need to share power with the opposition parties then in terms of the success of legislative amendments we could hypothesise that: 
- Virtually all ministerial amendments would succeed

- Virtually all opposition amendments would not succeed

- Amendments from Labour and Liberal parliamentarians will be more successful than amendments from opposition parliamentarians.

And if we accept that political culture/party cohesion ensures that the Scottish Parliament is more of a reactive than a policy making body then we could further expect that:

- Most ministerial amendments would be contested.

- The whip system at both stages of amendments would ensure that the Executive wins each vote on contested amendments.

\section{Analysing Legislative Amendments: Lessons from the European Parliament and}

\section{Westminster}

Unlike roll call analyses, amendment analyses for other countries are scarce. The most recent and detailed analyses of amendments come from studies of the European Parliament (EP). While not directly comparable (EP analyses focus on the relative salience of the different legislative procedures in operation) limitations of amendments analyses are discussed in this literature and are of use in guiding our analysis:

- It is difficult to determine the motives of the proposer from the amendment itself. In other words, an amendment may be proposed for inclusion, or proposed to highlight the proposer's beliefs on an issue (Earnshaw and Judge, 1996; Tsebelis et al., 2001; and Maurer, 2003).

- Amendments do not fully define interests - for example, the wishes of the European Parliament may already be addressed by the Council's first draft (Tsebelis et al., 2001, p. 576).

- The counting of amendment success does not take the substance of the amendments into account (Maurer, 2003, p. 242). This point is partially resolved by Kreppel's (2002) categories of textual, domain and policy amendments.

- Analysis of success rates does not take into account the number of points that are taken up and reintroduced by different actors (Maurer, 2003, p. 242). 
On this basis, Maurer (2003) rejects a focus on parliamentary amendments and instead employs a textual analysis, comparing the initial drafts proposed by the Council with the redrafted text following European Parliament amendments (see also Selck and Steunenberg, 2004 for an interests-based analysis). This approach is fruitful, and a change of the substance of bills following the legislative process may be a good indicator of legislative impact in this context. However, in the Scottish Parliament this may be of limited value without an analysis of the amendment process itself, since in Scotland (as in Westminster) it is the Executive that pursues most of the changes to that text. We argue that Maurer underestimates the value of detailed amendments analysis, particularly if criticisms on substance and initial authorship can be addressed.

Problems one and two (see above) deal with the issue of masked motives and similar interests respectively. In the case of masked motives, we acknowledge that there are likely to be numerous motives in the lodging of amendments. For instance, some may be designed to release ideological tensions or to reflect constituency concerns. To the extent that not all amendments are designed to influence the Executive then we should acknowledge that analyses of amendment successes in terms of legislative policy influence are likely to overestimate 'failures', and so underestimate the balance of power that the Parliament has with the Executive.

In the case of similar interests, parliamentary influence can be masked by Executive pre-emption (either on purpose or inadvertently). Again, because of this, we are likely to underestimate the balance of power that the Parliament has with the Executive. Tsebelis et al. (2001) regard similar interests more as an opportunity than a constraint per se. They argue that if, say, the Council is aware of the European Parliament's position, then it can incorporate this into its first draft. That way, amendments are only necessary when the two institutions do not agree. If this is the case, then amendments analysis focuses on disagreement that is important in any assessment of power dynamics.

Addressing the issue of substance, Kreppel (2002) devises three main categories: first, an amendment that merely clarifies the text of the bill; second, one which extends the applicability or domain of the text; and third, one which adds a significant policy dimension. While acknowledging the subjective nature of assigning amendments to these categories, Kreppel's analysis is limited by the lack of reliability testing. To tackle problem (3), we follow Kreppel in assigning differences in the quality of amendments. However, as we discuss below, 
we supplement substantive analysis with inter and intra-coder reliability measures to test the consistency of this value-based application.

Finally, we attempt to address the problem of initial authorship by measuring the extent to which MSPs withdraw their amendments in return for assurances by ministers that the spirit of the amendments will be reintroduced at a later stage in the process. By only measuring ministerial assurances and their realisation, we acknowledge that we are likely to miss those instances that are not mentioned in committee debates. Consequently, our findings are likely to underestimate the legislative impact of the Scottish Parliament.

When Griffith studied the impact of the House of Commons on the legislative process across three sessions he measured the annual number and proportion of amendments that were agreed to, withdrawn or 'negatived' by Ministers, Government backbenchers, and opposition members. In total, he found that whereas 99.9 per cent of Minister amendments were agreed to, success was around ten per cent for Government backbenchers and less than five per cent for opposition members (Griffith, 1974, pp. 195-207). Moreover, in three sessions he could only find evidence of nine non-ministerial substantive amendments that were agreed to (Griffith, 1974, p. 202).

However, as some of the more recent literature discussed above illustrates, we need to be aware of the nuances of the legislative process. While the Executive might move an amendment, it might also owe its origin to the non-Executive. Consequently, while we replicate Griffith's quantitative analysis by assessing success of amendments by Executive, Executive backbenchers, and non-Executive backbenchers, we develop the Griffith framework to examine more systematically the salience of initial authorship and qualitative differences in the types of amendment moved.

In terms of the qualitative differences in the types of amendments moved, the Westminster literature suggests that most ministerial amendments will be concerned with the fine-tuning of legislation. Judge (1993, pp. 110111) argues that Parliament devolves much decision-making responsibility to ministers and their departments and it expects any introduced bill to be a 'draft Act ${ }^{\mathrm{iv}}$. Fine-tuning entails correcting typographical errors and adding clarity and detail. Consequently, we hypothesise that: 
- Virtually all ministerial amendments will correct typographical errors, make 'consequential' ${ }^{\text {v }}$ changes, or relate to the detail and clarity of the bill, because it is the job of the Executive to make the bill work at each stage. The Executive presents the Bill as a draft Act and fine details are negotiated during the parliamentary process.

Therefore a 'face-value' analysis of amendment success will exaggerate the importance of ministerial amendments because it treats all amendments as equally substantive.

- A majority of ministerial amendments will be passed without controversy (because the Executive anticipates parliamentary reaction and the amendments are not controversial).

- By the last stage of the legislative process we would expect to see most substantive MSP concerns to have been considered and re-addressed by the Executive in the minister's name. This process also accounts for much of the non-Executive 'failure' of amendments, since many non-Executive amendments are withdrawn following ministerial assurance that the issue will be addressed at a later stage in the legislative process.

\section{Amendment Types}

Following systematic exploration and triangulation with the transcripts of all of the relevant Official Reports of parliamentary and committee proceedings we develop three broad categories of amendment types: typographical/consequential; detail/clarification; and substantive. Unlike the Kreppel (2002) analysis, our first category (typographical/consequential) distinguishes amendments that merely correct spelling and grammatical mistakes (typographical) as well as repetitive follow-through amendments that ensure bill consistency (consequential). Our second category (detail/clarification) is similar to Kreppel's first. It describes amendments that clarify meaning and emphasis without changing the tone of the bill, or amendments that add detail to existing provisions. Finally, a substantive amendment (like Kreppel's 'policy' category) alters the substance or tone of the bill (but within the context of the bill itself - that is, it cannot be a 'wrecking amendment' in the judgement of the committee convenor or Presiding Officer).

Both the categories and the coding of amendments are grounded in the amendment deliberations of the committees and Parliament as a whole (all data available from the Scottish Parliament web site ${ }^{\mathrm{vi}}$ ). In addition to 
this we track and note the parliamentary origins ${ }^{\text {vii }}$ of amendments across the legislative stages. We also analyse the success of those amendments by group that went to a vote, and we disaggregate unsuccessful amendments to gain more insight into 'failure'. Having explored the transcripts for the first ten Executive Bills, we devised a coding manual of amendment categories (labelled according to both the type of amendment and its fate) that included instructions and examples of each dimension measured. One trained individual conducted all coding to avoid problems of internal reliability that arise from inter-observer inconsistencies in coding practices. However, to address the issue of external reliability (can the findings be replicated by somebody else?) a second trained individual 'blindly' coded a sample $\mathrm{v}^{\mathrm{viii}}$ of the amendments and the extent of agreement was measured using Cohen's Kappa (k) coefficient. ${ }^{\text {ix }}$ Intra-coder reliability (can the findings be replicated by the same coder?) was also addressed as the first coder was subject to a 'blind' coding reassessment of a sample of the amendments and the extent of consistency was again measured using Cohen's Kappa.

\section{Data}

At the end of its first full session (1999-2003), the Scottish Parliament had passed 62 Bills (50 Executive, eight Member, three Committee and one Private). This paper investigates the nature of the balance of power between the Executive and the Parliament by analysing success of amendments and success by amendment type for the 50 Executive bills passed by the Parliament. The total number of amendments analysed was 9081 across 44 Executive bills (six of the 50 Executive bills were passed without amendment).

\section{Results}

The face-value figures of amendment numbers and success rates by author moved (see Table 1) shows that ministers move the most amendments and are nearly always successful. Across the 44 bills, ministers moved a total of 5725 amendments, or $63 \%$ of the total. If we also add the amendments from the Labour and Liberal backbenchers this figure raises to $73 \%$. Of the ministerial amendments, 5690 ( 99 per cent) were successful and only 35 (less than one per cent) were not successful ${ }^{\mathrm{x}}$. This compares with the non-Executive, where out of a total of 3356 amendments moved, only 415 (12 per cent) were successful and 2941 ( 88 per cent) were unsuccessful. Therefore, ministers account for 5690 (93\%) of the 6105 successful amendments. The degree of success for ministers is remarkably similar to the ministerial success that Griffith found in his 1967-71 study of House of Commons. The only difference is that the non-Executive fares a little better in the Scottish Parliament than they did in the House of Commons. Whereas amendments by Government backbenchers had around a one 
in ten success rate in the House of Commons, we find that amendments by backbenchers from the Executive parties have more than a one in five success rate. Similarly, whereas less than five per cent of opposition member amendments were found to be successful in the House of Commons, the corresponding figure of success for opposition members in the Scottish Parliament is higher at nine per cent. Among the opposition, while the Scottish National Party (SNP) were the most active in moving amendments, the Conservatives had a higher success rate.

\section{Table 1:}

\section{Success of Amendments in the Scottish Parliament}

\begin{tabular}{|c|c|c|c|c|c|}
\hline \multirow[t]{2}{*}{ Moved by } & \multirow{2}{*}{$\begin{array}{l}\text { Moved } \\
\text { N }\end{array}$} & \multicolumn{2}{|c|}{ Successful } & \multicolumn{2}{|c|}{ Unsuccessful } \\
\hline & & $\mathbf{N}$ & $\%$ & $\mathbf{N}$ & $\%$ \\
\hline Executive (a) & 5725 & 5690 & 99.4 & 35 & 0.6 \\
\hline$(\mathrm{Lab})$ & (3499) & $(3488)$ & $(99.7)$ & $(11)$ & $(0.3)$ \\
\hline (Lib Dem) & $(2226)$ & (2202) & (98.9) & $(24)$ & $(1.1)$ \\
\hline Non-Executive (b) & 3356 & 415 & 12.4 & 2941 & 87.6 \\
\hline (Lab/Lib Dem Total) & $(888)$ & (191) & $(21.5)$ & $(697)$ & $(78.5)$ \\
\hline (Lab) & $(527)$ & (119) & $(22.6)$ & $(408)$ & $(77.4)$ \\
\hline (Lib Dem) & $(361)$ & $(72)$ & (19.9) & $(289)$ & $(81.1)$ \\
\hline (Opposition Total) & $(2468)$ & $(224)$ & $(9.1)$ & (2244) & $(90.9)$ \\
\hline (SNP) & $(1457)$ & (128) & $(8.8)$ & (1329) & $(91.2)$ \\
\hline (Con) & $(791)$ & (91) & $(11.5)$ & $(700)$ & $(88.5)$ \\
\hline (Other) & $(220)$ & ( 5$)$ & $(2.3)$ & $(215)$ & $(97.7)$ \\
\hline Total $(a+b)$ & 9081 & 6105 & 67.2 & 2976 & 32.8 \\
\hline
\end{tabular}


Table 2:

Success of Amendments that went to a Vote in the Scottish Parliament

\begin{tabular}{|c|c|c|c|c|c|}
\hline \multirow[t]{2}{*}{ Moved by } & \multirow{2}{*}{$\begin{array}{l}\text { Vote } \\
\text { N }\end{array}$} & \multicolumn{2}{|c|}{ Successful } & \multicolumn{2}{|c|}{ Unsuccessful } \\
\hline & & $\mathbf{N}$ & $\%$ & $\mathbf{N}$ & $\%$ \\
\hline Executive (a) & 184 & 181 & 98.4 & 3 & 1.6 \\
\hline (Lab) & $(87)$ & ( 84$)$ & (99.6) & (3) & (3.4) \\
\hline (Lib Dem) & ( 97$)$ & (97) & (100) & (0) & $(0.0)$ \\
\hline Non-Executive (b) & 1004 & 87 & 8.7 & 917 & 91.3 \\
\hline (Lab/Lib Dem Total) & (154) & (40) & $(26.0)$ & (114) & (74.0) \\
\hline (Lab) & $(61)$ & (18) & $(29.5)$ & (43) & (70.5) \\
\hline (Lib Dem) & ( 93$)$ & (22) & $(23.7)$ & (71) & (76.3) \\
\hline (Opposition Total) & $(850)$ & (47) & (5.5) & (803) & (94.5) \\
\hline (SNP) & $(478)$ & ( 19) & ( 4.0$)$ & (459) & (96.0) \\
\hline (Con) & (253) & (26) & $(10.3)$ & (227) & (89.7) \\
\hline (Other) & (119) & ( 2$)$ & ( 1.7$)$ & (117) & (98.3) \\
\hline $\operatorname{Total}(a+b)$ & 1188 & 268 & 22.6 & 920 & 77.4 \\
\hline
\end{tabular}

Data includes all amendments that went to vote $(\mathrm{N}=1188)$ from the 50 Executive bills passed by the Scottish Parliament 1999-2003. $\mathrm{K}=+0.98 * *$ (inter-coder test) and $+1.0 * *$ (intra-coder test). $* * \mathrm{p}<.001$. For amendments of more than one author, disaggregation by party is based on the lead author's party.

Thirteen per cent $(\mathrm{N}=1188)$ of all amendments were forced to a vote (see Table 2). However, this figure masks much variation between the Executive and non-Executive. Whereas only three per cent of ministerial amendments are pushed to a vote, the figure is approximately one in three for non-Executive amendments, and more than one in two if we narrow our focus to exclude the four main parties. Where an amendment went to a 
vote we find that ministers were successful in 98 per cent of cases while the non-Executive were only successful in less than nine per cent of cases (see Table 2). When we disaggregate the proportion of non-Executive amendments that went to a vote we find that Labour/Liberal Democrat amendments were more than four times more likely to be successful (26 per cent) than opposition amendments (less than six per cent). Not only is success during votes largely the preserve of ministers, it is also far more likely among the Labour/Liberal nonExecutive coalition than it is the opposition. The most successful opposition party during votes is the Conservative Party (albeit with a paltry one in ten success rate).

Our findings in Tables 1 and 2 support most of our initial hypotheses. Virtually all ministerial amendments are successful, virtually all opposition amendments are not, and the amendments from Labour and Liberal parliamentarians are more successful than those of the opposition. However, while we find that ministers succeed in nearly all of their contested amendments, we do not find that most ministerial amendments are contested. Rather, we find the opposite - less than four per cent are contested. This finding can be interpreted in two different ways. First, the opposition may be reluctant to challenge ministerial amendments because of the futility of the exercise. The coalition parties have majorities on the committees and so can block opposition challenges. Alternatively, this finding might indicate that the vast majority of ministerial amendments actually meet with committee approval - suggesting a spirit of consensus among the parties. While both interpretations have their examples, we argue that the consensus explanation holds most sway since the futility argument fails to explain why, in comparison, over a third of all opposition amendments are forced to a vote. Our explanation is strengthened when we consider the type of amendments being moved.

As Kreppel (2002) illustrates, analyses of amendment successes fail to distinguish among amendment types. To make any sense of the nature of success we need to ask the following question: What proportion of successful amendments is substantive ${ }^{\mathrm{xi}}$ ?

Table 3:

A Qualitative Assessment of Successful Amendment Types

by Author in the Scottish Parliament 


\begin{tabular}{|c|c|c|c|c|c|c|}
\hline \multirow[t]{2}{*}{ Author } & \multicolumn{2}{|c|}{$\begin{array}{l}\text { Typographical/ Detail/ } \\
\text { Consequential }\end{array}$} & \multicolumn{2}{|c|}{ Clarification } & \multicolumn{2}{|l|}{ Substantive } \\
\hline & $\mathbf{N}$ & $\%$ & $\mathbf{N}$ & $\%$ & $\mathbf{N}$ & $\%$ \\
\hline Executive (a) & 3363 & 59.1 & 2108 & 37.0 & 219 & 3.8 \\
\hline (Lab) & (2074) & $(59.5)$ & $(1281)$ & $(36.7)$ & (133) & $(3.8)$ \\
\hline (Lib Dem) & $(1289)$ & $(58.5)$ & $(827)$ & $(37.6)$ & ( 86$)$ & $(3.9)$ \\
\hline Non-Executive (b) & 189 & 45.5 & 195 & 47.0 & 31 & 7.5 \\
\hline (Lab/Lib Dem Total) & (64) & $(33.5)$ & $(102)$ & $(53.4)$ & (25) & $(13.1)$ \\
\hline (Lab) & (27) & $(22.7)$ & ( 71) & $(59.7)$ & $(21)$ & $(17.6)$ \\
\hline (Lib Dem) & (37) & (51.4) & $(31)$ & $(43.1)$ & $(4)$ & $(5.6)$ \\
\hline (Opposition Total) & $(125)$ & $(55.8)$ & (93) & $(41.5)$ & $(6)$ & $(2.7)$ \\
\hline (SNP) & (64) & $(50.0)$ & $(61)$ & $(47.7)$ & ( 3 ) & $(2.3)$ \\
\hline (Con) & $(60)$ & $(65.9)$ & (28) & $(30.8)$ & ( 3 ) & $(3.3)$ \\
\hline (Other) & $(1)$ & $(20.0)$ & (4) & $(1.7)$ & $(0)$ & $(0.0)$ \\
\hline Total $(a+b)$ & 3552 & 58.2 & 2303 & 37.7 & 250 & 4.1 \\
\hline
\end{tabular}

\section{Key:}

Typographical/Consequential $=$ amendments that correct spelling and grammatical mistakes/repetitive followthrough amendments to ensure bill consistency.

Detail/Clarification $=$ amendments that provide necessary detail to complement existing substance/ amendments that clarify meaning and emphasis.

Substantive $=$ amendments that alter the existing substance or tone of the bill.

Table 3 shows the number and proportion of amendments that were successful by amendment type and by

author. It shows that only four per cent of successful ministerial amendments made substantive changes while

96 per cent related to typos, consequential amendments, details or clarifications. By contrast, eight per cent of

the non-Executive successes were substantive. These findings confirm our qualitative hypothesis that virtually all of the ministerial amendments would relate to fine-tuning of the draft legislation, and help explain why the majority of ministerial amendments are passed without controversy. Consequently, analysis by quality (and not just quantity) suggests a more interesting picture in which the vast majority of successful amendments deal with 
corrections and policy minutiae. Interpreted from this perspective, qualified data suggests that the Parliament is not as imbalanced vis-à-vis the Executive as figures of raw success indicated.

However, when we disaggregate the non-Executive amendments we find that the opposition have fared less well than the non- Executive Labour/ Liberal Democrat coalition (only six successful and substantive amendments compared with 24). Further disaggregation by party reveals that the Labour MSPs have been more successful with substantive amendments than the rest of the MSPs combined. Moreover, if we compare ministerial and non-Executive Labour/ Liberal Democrat substantive success with that of the opposition parties we find that the opposition parties account for less than one in 40 substantive successes. While accounting for amendment type does qualify the nature of ministerial successes, we still find that just as 93 per cent of all successful amendments come from ministers, so ministers author 88 per cent of all successful 'substantive' amendments.

However, we need to investigate this further. Like Maurer (2003) we argue that 'authorship' is rather more complex than it appears. Indeed, when we explored the committee transcripts we found that many of the successful substantive 'Executive' amendments were actually earlier non-Executive amendments that had been withdrawn typically on the proviso that the Executive would find the necessary legal jargon for the amended bill to make sense. Therefore we should ask the following:

- Of the substantive amendments relating to ministerial 'success', how many of these actually re-addressed earlier concerns (for example, Stage 2 amendments) of backbench MSPs? And,

- If we account for initial authorship, then to what extent does this make a difference to our understanding of the degree of power sharing between the Parliament and the Executive?

Ministers are usually very open and candid about the initial authorship of amendments. This is especially the case with MSPs (both coalition and opposition) where promises to look into amendments in exchange for their withdrawal at early stages are common.

Table 4:

A Qualitative Assessment of Successful Amendment Types

by Original Author in the Scottish Parliament 


\begin{tabular}{|c|c|c|c|c|c|c|}
\hline \multirow[t]{2}{*}{$\begin{array}{l}\text { Original } \\
\text { Author }\end{array}$} & \multicolumn{2}{|c|}{$\begin{array}{l}\text { Detail/ } \\
\text { Clarification }\end{array}$} & & \multicolumn{3}{|c|}{ Substantive } \\
\hline & $\mathbf{N}$ & $\%$ & & $\mathbf{N}$ & $\%$ & \\
\hline Executive & 1915 & 83.2 & & 157 & 62.8 & \\
\hline Non-Executive & 388 & 16.8 & & 93 & 37.2 & \\
\hline (Non-Executive Inspired) & (193) & $(8.4)$ & & $(62)$ & $(24.8)$ & \\
\hline (Non-Executive Presented) & & $(195)$ & $(8.4)$ & & (31) & $(12.4)$ \\
\hline Total & 2303 & 100 & & 250 & 100 & \\
\hline
\end{tabular}

Data includes all successful clarification, detail and substantive amendments $(\mathrm{N}=2542)$ for the 50 Executive bills passed by the Scottish Parliament 1999-2003. There is no breakdown by party because ministers often attribute authorship to committees rather than individual MSPs.

Table 4 illustrates that, even if we take initial authorship into consideration, ministers still account for over 80 per cent of the successful amendments relating to clarification and detail. However, this is no surprise since Parliament expects ministers to address these issues. As Judge (1993) argues, Parliament devolves this responsibility to ministers. More significantly, our figures suggest that of the 250 successful substantive ministerial amendments, 62 ( 25 per cent) were found to have addressed concerns initially raised by backbench MSPs. To reflect this, adjusted calculations show that while 157 (63 per cent) successful substantive amendments can be attributed to ministers, 93 (37 per cent) of the successful substantive amendments can be attributed to backbenchers. In other words, successful substantive amendments can be attributed to backbenchers in at least one out of three cases.

By taking into account origin of amendment within the parliamentary arena, we find evidence that backbenchers are relatively more influential than face-value data suggests. Moreover, we also find that this process does not suggest major party/ coalition bias. In fact, the opposite is marginally the case. We argue that this is because most ministers tend to support Labour MSPs in directly amending bills, whereas with opposition MSPs they 
prefer to offer a new amendment at a subsequent stage in exchange for a withdrawal. In most cases the effect is the same, since Labour MSPs initially withdraw, accept revisions by the Executive, then reintroduce amendments under their own name.

More importantly, we also find significant evidence of the role of committees in this process. Of the 62 nonExecutive 'inspired' substantive amendments, we find that approximately two-thirds are attributed ${ }^{\mathrm{xii}}$ to initial committee (rather than individual MSP) concerns. This initial concern usually comes from the committee in charge of Stage 2 of the relevant bill. However, the Subordinate Legislation Committee also plays a significant role in the constant reassertion of parliamentary process. Specifically, most bills contain general provisions stating that ministers may order statutory instruments or produce guidance in furtherance of the bill, after its completion. However, the committee tends to act to qualify this power by insisting on the requirement of parliamentary resolutions to accompany secondary legislation. In other words, it attempts to ensure that statutory instruments are subject to committee scrutiny and approval.

Our findings demonstrate a significant parliamentary role in the passage of substantive amendments which is not dominated by the majority party/coalition. Further, they allow us to reinterpret the apparently high levels of nonExecutive 'failure'.

Our analysis of committee reports and minutes reveal that most MSP amendments are not necessarily put forward to be accepted into the text of the bill. Disaggregating the number of non-Executive amendments that are unsuccessful $(\mathrm{N}=2941)$ reveals that 1636 (56 per cent) were withdrawn, 1219 (41 per cent) were rejected by vote (including those amendments that were consequential to those rejected), and 87 (three per cent) were superseded (where one amendment negates the applicability of another). While the coalition is much more willing to withdraw, the opposition still withdraws at least as much as it pushes amendments to a vote ${ }^{\text {xiii }}$.

Withdrawn amendments fall into three broad categories. First are those amendments designed to elicit debate or Executive response. Of these there are two main types. 'Holding' amendments are introduced to ensure that significant debate is secured for the issue. 'Probing' amendments are designed to enquire about the status quo and/or Executive intentions. The main point about these types of withdrawn amendments is that they are not really 'unsuccessful', since MSPs often do not intend these to be accepted per se. As an example, during the 
Stage 2 consideration of the Freedom of Information (Scotland) Bill, SNP MSP Michael Matheson tabled an amendment designed to probe the minister on the status and remit of statutory exemptions to the disclosure of information.

Second are those amendments that become unnecessary to pursue during the legislative process. Again, there are two main types. First, the Executive may explain why the amendment would not work or why the wording would be difficult to implement. As an example, during the Stage 2 consideration of the National Parks (Scotland) Bill, Liberal Democrat MSP John Munro tabled an amendment that sought to ensure that local interests would be 'fully' considered and 'positively engaged' during the preparation of national park proposals. Having received ministerial assurance that his wording could thwart progress on national park development and that statutory guidance on the incorporation of local interests was forthcoming, Munro withdrew his amendment. Second, MSPs often present amendment alternatives because they are unsure of their fate. For example, they may present one strong and one compromise amendment on the same subject. This is well demonstrated by Conservative MSP Murray Tosh's success ${ }^{\text {xiv }}$ in removing sections 51-60 (regarding workplace parking licensing schemes) of the Transport Bill. This substantial success caused Tosh to withdraw 15 amendments that became unnecessary.

Table 5:

Disaggregation of Unsuccessful Non-Executive Amendments

\begin{tabular}{|c|c|c|c|c|c|c|}
\hline \multirow[t]{2}{*}{ Author } & \multicolumn{2}{|c|}{$\begin{array}{l}\text { Rejection by Vote } \\
\text { (+ Consequential) }\end{array}$} & \multicolumn{2}{|l|}{ Withdrawn } & \multicolumn{2}{|c|}{ Superseded } \\
\hline & $\mathbf{N}$ & $\%$ & $\mathbf{N}$ & $\%$ & $\mathbf{N}$ & $\%$ \\
\hline Non-Executive & 1218 & 41.4 & 1636 & 55.6 & 87 & 3.0 \\
\hline (Lab/Lib Dem Total) & (131) & $(18.8)$ & $(545)$ & $(78.2)$ & $(21)$ & $(3.0)$ \\
\hline$(\mathrm{Lab})$ & $(53)$ & $(13.0)$ & (339) & $(83.1)$ & $(16)$ & (3.9) \\
\hline (Lib Dem) & $(78)$ & $(27.0)$ & $(206)$ & $(71.3)$ & $(5)$ & $(1.7)$ \\
\hline (Opposition Total) & $(1087)$ & $(48.4)$ & (1091) & $(48.6)$ & $(66)$ & $(2.9)$ \\
\hline$(\mathrm{SNP})$ & $(624)$ & $(47.0)$ & $(661)$ & $(49.7)$ & $(44)$ & $(3.3)$ \\
\hline (Con) & $(312)$ & $(44.6)$ & (379) & $(54.1)$ & ( 9 ) & $(1.3)$ \\
\hline
\end{tabular}


Data includes all non-Executive unsuccessful amendments $(\mathrm{N}=2941)$ for the 50 Executive bills passed by the Scottish Parliament 1999-2003.

Finally there are amendments that are addressed by the Executive. Of these, there are four main types. First, sometimes two amendments are similar and one is withdrawn in favour of the other (or is superseded). Indeed, the Executive often replicates MSP amendments at the same stage of debate to ensure that the non-Executive point is acknowledged in a form that is acceptable to the Executive. This is well exemplified by the debate on fuel policy within the Housing (Scotland) Bill. Several MSPs presented amendments to deal with this issue, but deferred to the minister when they were satisfied with the wording and detail. Second, ministers state that if the MSP withdraws the amendment at this stage then the Executive will address the issue and amend at a later stage. Again, the point is that non-success does not necessarily equate with 'failure', since the substance of the amendment is accepted and reshaped by the Executive. This is well illustrated in the Stage 3 debate of the Water Environment and Water Services (Scotland) Bill when SNP MSP Fiona McLeod stated that 'the SNP and the committee must acknowledge the consideration that the Executive has shown in listening to what we have said' ${ }^{\mathrm{xv}}$ Of course, this is not to suggest that the Executive always accept the points word-for-word. Rather, it typically addresses a broad concern or follows a broad aim raised by the non-Executive. The 'spirit' of the amendment or the commitment to solve a problem is maintained even if the wording is not ${ }^{\mathrm{xvi}}$. Third, some amendments withdrawn at Stage 2 are reintroduced at Stage 3 if the MSP does not feel that her/ his amendment has been fully addressed by the Executive. Fourth, some amendments are withdrawn at Stage 2 and reintroduced by MSPs at Stage 3 following Executive help with redrafting.

Therefore, the large proportion of withdrawals, coupled with the significant number of MSP-based substantial Executive successes, shows a process that is more open to power sharing or consensus than the face-value figures suggest. This furthers the argument that the legislative process, when disaggregated and qualified, shows rather more evidence of complex power relations existing between the Executive and the Parliament.

\section{Conclusion and Implications}

In this paper we have analysed the extent to which the Scottish Parliament makes a difference to Executive legislation during the amendments process. While we find that the Executive dominates in the success of 
amendments, there is evidence of greater balance between the Executive and the Parliament (including the opposition) when we control for amendment type and initial authorship. The willingness of MSPs to withdraw amendments, coupled with the mainly sincere (and demonstrated) ministerial commitment to address MSP concerns, results in a combined success that the face-value figures do not illustrate. Our qualified findings indicate that the balance of power between the Executive and the Parliament and within the Parliament is not as Executive and coalition-party centric as it initially appears.

Our findings have interesting implications for those who study the impact of parliaments. Clearly our investigation of the Scottish Parliament suggests that the operation of the UK Parliament demands closer inspection than that afforded by Griffith (1974). However, our conclusions also provide a challenge for comparative European analysis. Such accounts need to go beyond a focus on the institutional set-up of Western European countries or analyses at the bill, rather than amendment, level. Individual country-level analyses of the detailed amendments process are required to ascertain the generalisability of our findings.

Word count (everything): 8315

Word count (excluding references, endnotes and first page): 6619

\section{References}

Arter, D. (2002a) 'The Committee System in the New Scottish Parliament: the Motor of a "New Politics"?' Paper prepared for the Third Scottish-Nordic Research Network Conference, Ardoe House Hotel, Aberdeen, 2425 May 2002.

Arter, D. (2002b) 'On Assessing Strength and Weakness in Parliamentary Committee Systems: Some Preliminary Observations on the New Scottish Parliament', The Journal of Legislative Studies, 8, 2, 93-117

Arter, D. (2004) 'The Scottish Committees and the Goal of a "New Politics": A Verdict on the First Four Years of the Devolved Scottish Parliament', The Journal of Contemporary European Studies, Vol. 12, 2. (forthcoming).

Cairney, P. and Keating, M. (forthcoming) 'Sewel Motions in the Scottish Parliament', Scottish Affairs

Cramer, D. (1998) Fundamental Statistics for Social Research. London: Routledge.

Earnshaw, D. and Judge, D. (1996) 'From Co-operation to Co-decision: The European Parliament's Path to Legislative Power' in Richardson, J. (ed) Policy Making in the European Union. London: Routledge, pp. 96-126

Griffith, J.A.G. (1974) Parliamentary Scrutiny of Government Bills. George Allen and Unwin Ltd.

Hassan, G. (ed) (1999) A Guide to the Scottish Parliament. Edinburgh: The Stationery Office.

Hassan, G., and Warhurst, C. (eds) (2000) The New Scottish Politics. Norwich: The Stationery Office.

Hazell, R. (ed) The State and the Nations 2000. Thorverton: Imprint Academic. 
Hazell, R. (ed) The State and the Nations 2003. The Third Year of Devolution in the United Kingdom. Exeter: Imprint Academic.

Jordan, G. (ed) (1990) The Commercial Lobbyists: Politics and Profit in Britain. Aberdeen: Aberdeen University Press

Judge, D. (1993) The Parliamentary State. London: Sage.

Keating, M. (2005) The Government of Scotland: Public Policy Making after Devolution. Edinburgh: Edinburgh University Press.

Keating, M., Stevenson, L., Cairney, P. and MacLean, K. (2003) 'Does Devolution Make a Difference? Legislative Output and Policy Divergence in Scotland', The Journal of Legislative Studies, 9 (3), pages forthcoming.

Kreppel, A. (2002) 'Moving Beyond Procedure: An Empirical Analysis of European Parliament Legislative Influence', Comparative Political Studies, 35, 7, 784-813

Landis, J.R., and Koch G. G. (1977) 'The Measurement of Observer Agreement for Categorical Data', Biometrics, 33, 159-74.

Lijphart, A. (1999) Patterns of Democracy. New Haven: Yale University.

Lynch, P. (2001) Scottish Government and Politics. Edinburgh: Edinburgh University Press.

Mattson, I. and Strøm, K. (2004) 'Committee Effects on Legislation' in (eds) Döring, H. and Hallerberg, M. Patterns of Parliamentary Behaviour. Aldershot: Ashgate.

Maurer, A. (2003) 'The Legislative Powers and the Impact of the European Parliament', Journal of Common Market Studies, 41, 2, 227-47

McFadden, J., and Lazarowicz, M. (2000) The Scottish Parliament: An Introduction. Edinburgh: T. and T. Clark.

Mitchell, J. (1996) Strategies for Self-Government: The Campaigns for a Scottish Parliament. Edinburgh: Polygon.

Mitchell, J. (2000) 'New Parliament, New Politics in Scotland', Parliamentary Affairs, 53, 605-21.

Monserud, R. A., and Leemans, R. (1992), 'The Comparison of Global Vegetation Maps', Ecological Modelling, 62, 275-93.

Neuendorf, Kimberly A. (2002), The Content Analysis Guidebook. London: Sage Publications.

Norton, P. (1998) Parliaments and Governments in Western Europe. London: Frank Cass.

Olson, D. and Norton, P. (1996) 'Parliaments in Adolescence' in Olson, D. and Norton, P. (eds) The New Parliaments of Central and Eastern Europe. London: Frank Cass.

Packenham, R. (1970) 'Legislatures and Political Development' in Kornberg A., and Musolf, L. D. (eds), Legislatures in Developmental Perspective. Durham NC: Duke University Press.

Page, E.C. (2003) 'The Civil Servant as Legislator: Law Making in British Administration', Public Administration, 81, 4, 651-79

Scottish Constitutional Convention (1995) Scotland's Parliament, Scotland's Right, http://www.almac.co.uk/business_park/scc/scc-rep.htm\#

Scottish Council Foundation $\left(26^{\text {th }}\right.$ June 2002), Rethinking Representation, Synopsis for The Scotsman. 
Scottish Office (1997), Scotland's Parliament. Edinburgh: Stationery Office.

Scottish Parliament web site, http://www.scottish.parliament.uk/

Scottish Parliament Procedures Committee Report (20 ${ }^{\text {th }}$ March 2003), The Founding Principles of the Scottish Parliament: the Application of Access and Participation, Equal Opportunities, Accountability and Power Sharing in the Work of the Parliament, http://www.scottish.parliament.uk/S1/official_report/cttee/proced03/prr03-03-01.htm

Selck, T.J. and Steunenberg, B. (2004) 'Between Power and Luck: the European Parliament in the European Union Legislative Process', European Union Politics, 5, 1, 25-46

Shephard, M., McGarvey N. and Cavanagh M. (2001) ' New Scottish Parliament, New Scottish Parliamentarians?' Journal of Legislative Studies, 7 (2), 79-104.

Shephard, M. (2001-2004) Scottish Parliament quarterly reports in 'Nations and Regions: The Dynamics of Devolution', The Constitution Unit (Quarterly Monitoring Programme), http://www.ucl.ac.uk/constitutionunit/leverh/pub.htm

Shephard, M. and Cairney, P. (forthcoming 2004) 'Consensual or Dominant Relationships with Parliament? A Comparison of Administrations and Ministers in Scotland', Public Administration

Taylor, B. (1999) The Scottish Parliament. Edinburgh: Polygon.

Trench, A. (ed) (2001) The State of the Nations 2001: The Second Year of Devolution in the United Kingdom. Thorverton: Imprint Academic.

Trench, A. (ed) (2004) Has Devolution Made a Difference? The State of the Nations 2004. Exeter: Imprint Academic.

Tsebelis, G., Jensen, C.B., Kalandrakis, A. and Kreppel, A. (2001) 'Legislative Procedures in the European Union', British Journal of Political Science, 31, 573-99

Watson, M. (2001) Year Zero: An Inside View of the Scottish Parliament. Edinburgh: Polygon.

Winetrobe, B. K. (2001) Realising the Vision: A Parliament with a Purpose. An Audit of the First Year of the Scottish Parliament, London: The Constitution Unit.

\footnotetext{
${ }^{\mathrm{i}}$ Hassan and Warhurst, 2000; Hazell et al, 2000, 2003; Lynch, 2001; Shephard, 2001-2004; Trench et al, 2001, 2004; Watson, 2001; and Winetrobe 2001.

ii In the Scottish Parliament 'session' refers to a full term between elections. In Westminster it refers to one year.

${ }^{\text {iii }}$ We therefore leave a discussion of the role of committee and member bills to another paper.

iv See Jordan (1990). The 'draft Act' does not undermine the parliamentary process. On the contrary, our analysis of the Scottish Parliament suggests that MSPs are likely to protest more if the bill is not drafted well enough. As in Westminster, poor drafting of bills as introduced leads to a raft of ministerial amendments which may change the substance of the bill and allow Parliament less time to scrutinise legislation (see Griffith, 1974: p.88).

${ }^{\mathrm{v}}$ Consequential amendments are follow-through amendments that are needed if a prior amendment to a bill is to make any sense. For instance, an amendment that removes a word from a bill may require that five subsequent mentions of that word are also removed from that bill. Clearly, while the first amendment may alter the substance of the bill, it would be disingenuous to count the five consequential amendments that it triggered as being equally substantive. They are a necessary result of the line-by-line approach favoured by Parliament. ${ }^{\mathrm{vi}}$ http://www.scottish.parliament.uk/

${ }^{\text {vii }}$ Although the original source for many of the amendments moved is often extra-parliamentary (in particular from interest groups), we are interested in identifying the MSP or MSPs who first move(s) an amendment in the parliamentary arena.

viii Our reliability sub-sample includes over 10\% (933 out of 9081 amendments) of cases and exceeds sampling guidelines for an $\mathrm{N}$ of this size (see discussion of current methods literature in Neuendorf 2002, pp.158-59). The
} 
nature of our data (especially the need to identify consequential amendments) and the demands of our measures (especially the need to control for initial authorship across legislative stages) means that we had to select our sub-sample from a random sample of Bills and not a random sample of amendments per se. Consequently, the sub-sample analysis checks reliability for all amendments of the Bills that were randomly selected. In total six bills (with a total of 933 amendments) were selected for the reliability tests.

${ }^{\text {ix }}$ Cohen's Kappa (k) provides an index of agreement between coders that controls for the impact of agreements by chance. Kappa assumes nominal-level data and a $\mathrm{k}$ value of +1 indicates perfect agreement, zero chance agreement, and a negative $\mathrm{k}$ (up to -1 ) indicates less than chance agreement (Cramer, 1998: p.384). The formula for $\mathrm{k}$ is: (observed proportion of agreement - proportion of agreement expected by chance)/1 - proportion of agreement expected by chance. However, $\mathrm{k}$ is calculated in this paper via the crosstabs procedure in SPSS. In interpreting Kappa (k), Banerjee et al. propose the following standards: a value of +0.75 to 1.0 indicates excellent agreement beyond chance; +0.40 to +0.75 , fair to good agreement beyond chance; and below +0.40 , poor agreement beyond chance (Banerjee et al., 1999 quoted in Neuendorf 2002, p.143). Other interpretations of $\mathrm{k}$ in the literature are broadly similar (see Landis and Koch, 1977; and Monserud and Leemans, 1992 for example).

${ }^{x}$ For a discussion of these, see Shephard and Cairney (forthcoming 2004).

${ }^{x i}$ Substantive amendments are those amendments that at least extend the scope of the bill or alter its tone in at least one section.

${ }^{x i i}$ Either by the Executive or the committee itself (or both). While it may be in the interests of both actors to maintain a pretence around the significance of this issue, our analysis of the Official Reports does support this picture.

${ }^{x i i i}$ Indeed, if we remove Tommy Sheridan (SSP, 98 (84\%) rejections) and Bill Aitken (Conservative, 128 (76\%) rejections) then the rejection rate drops to $44 \%$ and withdrawal to $53 \%$.

${ }^{x i v}$ Although Tosh cannot take all of the credit - see Keating et al (forthcoming).

${ }^{x v}$ Fiona McLeod, Scottish Parliament Official Report (29 ${ }^{\text {th }}$ January 2003, col. 17540) http://www.scottish.parliament.uk/S1/official_report/session-03/sor0129-02.htm

${ }^{\mathrm{xvi}}$ However, for a different view on these proceedings from a Whitehall perspective, see Page (2003). 